\title{
Biosynthesis and Expression of Zona pellucida Glycoproteins in Mammals
}

\author{
F. Sinowatz $^{a} \quad$ S. Kölle ${ }^{a}$ E. Töpfer-Petersen ${ }^{b}$ \\ aLehrstuhl für Tieranatomie II, University of Munich, and b Institut für Reproduktionsmedizin der \\ Tierärztlichen Hochschule Hannover, Germany
}

\author{
Key Words \\ Zona pellucida $\cdot$ Synthesis $\cdot$ Mammals
}

\begin{abstract}
The zona pellucida (ZP) is an extracellular matrix surrounding the oocyte and the early embryo that exerts several important functions during fertilization and early embryonic development. The ZP of most mammalian species is composed of three glycoproteins (ZPA, ZPB, $Z P C)$, products of the gene families $Z P A, Z P B$ and $Z P C$ that have been found to be highly homologous within mammalian species. Most data on the structure and function of the ZP are obtained from studies in mouse. New data from pig and other domestic animals, however, indicate that the mouse model does not hold for all other species. Whereas in the mouse ZPB is the primary sperm receptor, in the pig ZPA has been shown to possess receptor activity. Contrary to the mouse, where the growing oocyte is the only source of zona glycoproteins,
\end{abstract}

\begin{tabular}{ll}
\hline Abbreviations used in this paper \\
\hline COC & cumulus-oocyte complex \\
GlcNAc & N-acetylglucosaminyl \\
ZP & zona pellucida \\
\hline
\end{tabular}

\begin{tabular}{ll}
\hline KARGER & ( ) 2001 S. Karger AG, Basel \\
Fax +4161306 1234 & 1422-6405/01/1682-0024\$17.50/0 \\
$\begin{array}{l}\text { E-Mail karger@karger.ch } \\
\text { www.karger.com }\end{array}$ & $\begin{array}{l}\text { Accessible online at: } \\
\text { www.karger.com/journals/cto }\end{array}$
\end{tabular}

in domestic animals these proteins are expressed in both the oocyte and granulosa cells in a stage-specific pattern and may play also a role in granulosa cell differentiation. In several mammalian species, the epithelial secretory cells of the oviduct synthesize and secrete specific glycoproteins (oviductins) that become closely associated with the ZP of the ovulated oocyte. Once bound to the ZP, oviductin molecules could act as a protective layer around the oocyte and early embryo by virtue of their densely glycosylated mucin-type domains.

Copyright $@ 2001$ S. Karger AG, Basel

\section{Introduction}

The zona pellucida $(\mathrm{ZP})$ is a transparent extracellular matrix surrounding mammalian oocytes and preimplantation embryos [Denker, 2000; Herrler and Beier, 2000; Sinowatz et al., 2000]. It forms a viscous border between oolemma and the innermost layer of follicle cells (corona radiata) (fig. 1). Cellular processes extend from the innermost follicle cells, through the ZP, and form gap junctions with egg plasma membrane [Wassarman et al., 1998]. The $\mathrm{ZP}$ is intimately involved in several critical stages of fertilization. It provides receptors for the relatively speciesspecific attachment and binding of capacitated sperm and is involved in the subsequent induction of the sperm acrosome reaction [Florman and Storey, 1982; Cherr et al.,

Prof. F. Sinowatz

Lehrstuhl für Tieranatomie II, University of Munich

Veterinärstrasse 13, D-80539 Munich (Germany)

Tel. +498921802563, Fax +498921802569

E-Mailf.sinowatz@anat.vetmed.uni-muenchen.de 
1986; Berger et al., 1989]. In most species certain, exposed oligosaccharide chains of the ZP and complementary carbohydrate binding proteins on the sperm-oocyte interface mediate, at least in part, the initial binding and recognition between the sperm and the ZP [Bedford, 1977; Aitken, 1995; Sinowatz et al., 1997; Hoshiba and Sinowatz, 1998]. Removal of the ZP eliminates the barrier to in vitro fertilization of egg by sperm from different species [Wassarman et al., 1998]. After penetration of the first spermatozoon, the ZP is modified and serves as a site of secondary block to polyspermy [Wassarman, 1982; Yanagimachi, 1988, 1994]. In addition to its role in fertilization the matrix proteins of the ZP appear to be important for the organization and differentiation of granulosa cells and folliculogenesis and provide protection from physical and environmental damage.

\section{Morphology and Glycoprotein Constituents of the ZP}

The ZP of mammalian oocytes is a transparent, extracellular matrix constructed from only three glycoproteins, which build its typical fibrogranular structure [Wassarman and Mortillo, 1991] by noncovalent interactions. Each of the glycoproteins is heterogeneous with respect to $\mathrm{M}_{\mathrm{r}}$ due to extensive and heterogeneous glycosylation of a unique polypeptide with both asparagine $(\mathrm{N})$-linked (complex-type) and serine/threonine-(O)-linked oligosaccharides [Wassarman et al., 1998]. The oligosaccharides are both sulfated and sialylated [Noguchi and Nakano, 1992; Liu et al., 1997], which additionally contributes to $\mathrm{M}_{\mathrm{r}}$ heterogeneity and makes all three glycoproteins relatively acidic [Nakano and Yonezawa, 2001]. The most obvious interspecies difference is the thickness of the $\mathrm{ZP}$ varying from 1 to $2 \mu \mathrm{m}$ in the opossum, $5 \mu \mathrm{m}$ in mouse, from 13 to $16 \mu \mathrm{m}$ in human and pig and $27 \mu \mathrm{m}$ in cow [Dunbar et al., 1989, 1994]. In many species the ZP is morphologically segregated in layers. There is a distinct asymmetry between the inner and outer layers [Philips and Shalgi, 1980; Ahuja and Bolwell, 1983; Shalgi and Raz, 1997] which can be defined using lectins and ZPspecific antibodies. When visualized by scanning electron microscopy, the mammalian ZP is found to be composed of a network dispersed with numerous pores [Vanroose et al., 2000] and with morphologically dissimilar internal and external surfaces. The external surface of the ZP presents a characteristic 'Swiss cheese' appearance and the internal surface shows a regular rough appearance [Philips and Shalgi, 1980; Keefe et al., 1997].
Variations in the morphological architecture of the ZP exist between species [Vanroose et al., 2000]. When the porous surface is compared among species, the smallest pores are found in the ZP of cow, the largest pores occur in the $\mathrm{ZP}$ of mouse and cat. The pores appear always to be largest at the outer surface of the ZP and decrease in size centripetally [Nikas et al., 1994]. The pore shape varies within and between the zonae of different species, but many zonae show a more elliptical than circular shape. The pores of the zona are more or less randomly distributed in all species studied except cat, where a trend towards a concentric pore arrangement exists [Vanroose et al., 2000]. The porous nature of the $\mathrm{ZP}$ allows the penetration of relatively large molecules such as immunoglobulins. On the other hand, small molecules, such as heparin, are prevented from penetrating the ZP. Obviously, the ability of molecules to pass this extracellular matrix does not primarily depend on the size of the penetrating molecule but also on other biochemical or physicochemical properties, like for example surface charge [Shivers and Dunbar, 1997]. Since embryo transfer has become increasingly important during the last years, questions have arisen concerning the risk of virus transmission through embryos and epidemiological complications of embryo transfer, but it could be demonstrated in bovine that an intact zona of in vitro-produced embryos acts perfectly well as a protective barrier against the two most important viral pathogens in cattle, bovine herpesvirus- 1 and bovine viral diarrhea virus [Vanroose et al., 1997, 1998].

The architecture of the ZP changes during maturation of the oocyte and fertilization. Recently, the surface of the bovine $\mathrm{ZP}$ of immature oocytes, in vitro maturing and in vitro matured oocytes and in vitro inseminated oocytes was studied by Suzuki et al. [1994]. They could demonstrate that the fine structure of immature oocytes is characterized by a network with numerous wide meshes and deep holes. After maturation, this network appears to be finer and the meshes and holes seem to be less deep. No meshes have been found on the ZP of inseminated oocytes, probably due to a fusion of several layers of the network.

Reports concerning the properties of the $\mathrm{ZP}$ in mouse provided insight into the molecular organization of the ZP matrix [Bleil and Wassarman, 1980, 1988; Wassarman, 1999]. According to their electrophoretic mobility the glycoproteins of mouse ZP are denoted mZP1 (200 $\mathrm{kD}$; dimer), mZP2 (120 kD), and mZP3 (83 kD). In mice these glycoproteins are exclusively synthesized by the growing oocyte. Two of the glycoproteins, mZP2 and $\mathrm{mZP} 3$, interact with each other forming heterodimeric 
Table 1. Molecular weights of $\mathrm{ZP}$ proteins in different mammalian species

\begin{tabular}{|c|c|c|c|}
\hline Species & $\begin{array}{l}\text { Zona gene family/ } \\
\text { ZP protein }\end{array}$ & $\begin{array}{l}\text { Molecular } \\
\text { weight, } \mathrm{kD}\end{array}$ & References \\
\hline \multirow[t]{3}{*}{ Human } & $\mathrm{ZPB} / \mathrm{ZP} 1$ & $80-92$ & Bercegeay et al. [1995] \\
\hline & $\mathrm{ZPA} / \mathrm{ZP} 2$ & $58-66$ & Harris et al. [1994] \\
\hline & ZPC/ZP3 (low-high) & $54-62(58-72)$ & \\
\hline \multirow[t]{3}{*}{ Mouse } & $\mathrm{ZPB} / \mathrm{ZP} 1$ & 200 & Bleil and Wassarman [1980] \\
\hline & ZPA/ZP2 & 120 & Harris et al. [1994] \\
\hline & ZPC/ZP3 & 83 & \\
\hline \multirow[t]{3}{*}{ Rabbit } & $\mathrm{ZPB} / \mathrm{ZP} 1$ & $68-125$ & Dunbar et al. [1989] \\
\hline & ZPA/ZP2 & $81-100$ & Harris et al. [1994] \\
\hline & ZPC/ZP3 & $100-132$ & \\
\hline \multirow[t]{5}{*}{ Pig } & ZPA/ZP1 & 80-90 & Hedrick and Wardrip [1986] \\
\hline & ZPA/ZP2 & $60-65$ & Harris et al. [1994] \\
\hline & $\mathrm{ZPB} / \mathrm{ZP} 3 \alpha$ & 55 & \\
\hline & $\mathrm{ZPC} / \mathrm{ZP} 3$ & 55 & \\
\hline & ZPA/ZP4 & $20-25$ & \\
\hline \multirow[t]{4}{*}{ Cow } & ?/ZP1 & 78 & Noguchi et al. [1994] \\
\hline & $\mathrm{ZPA} / \mathrm{ZP} 2$ & 64 & Harris et al. [1994] \\
\hline & $\mathrm{ZPB} / \mathrm{ZP} 3 \alpha$ & 21 & \\
\hline & ZPC/ZP3 & 21 & \\
\hline
\end{tabular}

units that are periodically arranged in long filaments. These filaments appear to be interconnected by ZP1, the largest mouse ZP protein [Wassarman and Mortillo, 1991]. Each of these glycoproteins consists of a unique polypeptide that is heterogenously glycosylated with both complex-type asparagine N-linked and serine/threonineO-linked oligosaccharides [see also Nixon et al., 2001; Wassarman and Litscher, 2001].

Disruption of the $m Z P 3$ gene by targeted mutagenesis [Wassarman et al., 1998] yields mice heterozygous $\left(\mathrm{mZP3}^{+/-}\right)$or homozygous $\left(\mathrm{mZP3}^{-/-}\right)$for the null mutation. Female mZP3 +/- mice appeared to be as fertile as wild-type females, despite the fact that their eggs had only a thin $(2.7 \mu \mathrm{m}) \mathrm{ZP}$. Eggs of mZP3 -/- mice did not synthesize a ZP and were completely infertile. Additionally, follicular development was often retarded in mZP3 -/mice. This was manifested in a reduced ovarian weight, reduced number of Graafian follicles and reduced number of fully grown oocytes. It was postulated [Wassarman et al., 1998] that the pleiotropic effects of the homozygous null mutation on oocyte and follicle development may be due, at least in part, to disruption of intercellular communication between growing oocytes and their surrounding follicular cells.

In the last few years it became clear that in a wide variety of mammals, including the human and domestic species, the ZP is composed of a small number of glycoproteins that are closely related [Skinner et al., 1996]. The amino acid sequences of ZP glycoproteins in mammals and corresponding vitelline membrane protein in lower vertebrates, like fish, amphibians and birds, have been found to be remarkably well conserved during evolution. The similarity of the polypeptides to the mouse zona proteins $\mathrm{mZP} 1, \mathrm{ZP} 2$ and ZP3 are ranging from 40 to $90 \%$ [Wassarman, 1999]. For example, the positions of the 13 cysteine residues as well as all of the recognizable domains of the MZP3 polypeptide are conserved in human ZP3 polypeptide. This points to a significant evolutionary link between the glycoproteins of the vitelline envelope of nonmammalian eggs and the zona proteins of mammalia. It has been proposed that these corresponding glycoproteins play essential structural roles in assembling the extracellular coats during oogenesis [Wassarman, 1999].

The glycoproteins of the $\mathrm{ZP}$ are the products of three major gene families referred to as $Z P A, Z P B$ and $Z P C$ according to the size of their cDNAs [Harris et al., 1994; Jegenow and Fickel, 1999]. The genes encoding the zona proteins ZPA, ZPB and ZPC of several mammalian species have been cloned. A relatively high degree of conservation of the gene sequences was found. Furthermore, in different species the primary polypeptide structure including the number and position of most cysteine residues and potential N-glycosylation sites is highly conserved [Harris et al., 1994]. Additionally, the intron/exon organization of each protein familiy is similar [McLeskey et al., 1998]. The characteristics of the zona proteins from dif- 
ferent domestic species and their nomenclature are listed in table 1 . The diversity in molecular mass between different species is due to high glycosylation of the ZP glycoproteins [Shalgi and Raz, 1997].

Pattern-based sequence analysis of ZP cDNAs and protein sequencing revealed several structural ZP domains within the zona glycoproteins, for instance the socalled ZP module which has been identified in all three $\mathrm{ZP}$ families. The ZP module consists of a 260 -amino acid sequence, containing 8 conserved cysteine residues as well as a conserved hydrophobicity pattern, polarity and turnforming tendency at numerous positions [Bork, 1992; Bork and Sander, 1992]. The strictly conserved cysteine residues imply a similiar organization of disulfide bonds. Additionally, all three ZP families possess an N-terminal hydrophobic signal sequence, a furin-processing site and a C-terminal hydrophobic transmembrane domain [Bork and Sander, 1992; McLeskey et al., 1998].

In the ZPB family there is an additional domain called the trefoil domain, which may increase resistance to proteolytic degradation [Bork, 1993]. The ZP module containing a 40-amino acid signature sequence is conserved in the ZP1 of all species except of mouse. Similarily, the trefoil domain, characterized by a 22-amino acid signature sequence, is altered in mouse ZP1 [McLeskey et al., 1998]. Such differences in the structure of ZP1 may point to differences in functions of ZP1 proteins between rodents and other mammalian species.

\section{Synthesis of ZP Glycoproteins}

The origin of the mammalian $\mathrm{P}$ glycoproteins is still controversial. Three theories have been developed proposing that glycoproteins are synthesized (1) by the oocyte only, (2) by the follicle cells only and (3) by both the oocyte and the follicle cells. There has been recent evidence that the contribution of follicle cells to the production of zona components is species specific. Thus, in mice possessing only a thin ZP $(6.2-1.9 \mu \mathrm{m})$ [Wassarman et al., 1998], zona glycoproteins and their transcripts are exclusively synthesized by the oocyte [Haddad and Nagai, 1977; Fléchon et al., 1984; Kimura et al., 1994; Epifano et al., 1995]. In vitro studies confirmed that mice oocytes are capable of synthesizing all zona proteins [Bleil and Wassarman, 1988].

In contrast, investigations in other species such as human [Grootenhuis et al., 1996], monkey [Grootenhuis et al., 1996; Martinez et al., 1996], rabbit [Dunbar et al., 1994; Grootenhuis et al., 1996], dog [Tresoriero, 1981], pig [Sinowatz et al., 1995; Kölle et al., 1996] and cow [Kölle et al., 1998] have shown that both the oocyte and the follicle cells contribute to the synthesis of zona glycoproteins. Characteristically, these species possess a welldeveloped zona. As the rate of protein synthesis by the oocyte is too low to account for the oocyte's weight plus that of its zona, follicle cells have to be involved in the synthesis of the proteins [Schultz et al., 1979]. These findings have been substantiated by in vitro studies on granulosa cells which were able to secrete ZP components. Moreover, some ZP proteins can be produced in the absence of oocytes in vivo [Skinner et al., 1984].

In situ hybridization studies and immunohistochemical investigations done in our laboratory demonstrated a change in the synthesis of ZP proteins and their mRNA in the course of ontogenesis (table 2). During follicular development of the porcine and bovine ovary, the protein ZPC and its transcript are mainly localized in the oocytes of primordial and primary follicles [Sinowatz et al., 1995; Kölle et al., 1996, 1998; Totzauer et al., 1998] (fig. 2). In secondary follicles, both the oocyte and the follicle cells contribute to the synthesis of ZPC and its mRNA. In tertiary and preovulatory follicles ZPC and its transcripts are mainly found in the cytoplasm of the corona radiata cells. Whereas the bovine oocyte is involved in ZP synthesis during all stages of follicular development, porcine oocytes of tertiary follicles stop synthesizing ZPC. This result intimates a species-specific differential expression of these zp proteins in the adult ovary [Kölle et al., 1996, 1998]. Moreover, investigations in fetal ovaries have shown that zona proteins are synthesized by follicle cells already during prenatal development. In the bovine fetus, ZPC is localized in oocytes of primordial and primary follicles as well as in both oocyte and follicle cells of secondary and tertiary follicles [Totzauer et al., 1998]. The culture medium essentially influences synthesis of ZPC in follicle cells during in vitro maturation of bovine cumulus-oocyte complexes (COCs). Thus, the cumulus cells of COCs maturated in tissue culture medium 199 supplemented with bovine FSH, bovine LH and estrus cow serum show high amounts of ZPC in their cytoplasm. In contrast, in COCs maturated in tissue culture medium 199 without supplements ZPC synthesis is reduced. As FSH, LH and estrous cow serum have been shown to enhance the frequency of fertilization and to support blastocyst development [Schellander et al., 1990], the enhanced viability of the COCs maturated in the presence of these supplements seems to be correlated to an increased ability of synthesizing ZPC [Kölle et al., 1998]. 
Table 2. Differential expression of ZPC mRNA and protein during ontogenesis of the bovine ovary

\begin{tabular}{|c|c|c|c|c|c|}
\hline Age & Tissue & $\begin{array}{l}\text { Primordial } \\
\text { follicle }\end{array}$ & $\begin{array}{l}\text { Pimary } \\
\text { follicle }\end{array}$ & $\begin{array}{l}\text { Secondary } \\
\text { follicle }\end{array}$ & $\begin{array}{l}\text { Tertiary } \\
\text { follicle }\end{array}$ \\
\hline \multirow[t]{3}{*}{ Adult } & Ooocyte & ++ & ++ & + & + \\
\hline & Granulosa cells & $+/-$ & + & ++ & + \\
\hline & Cells of the cumulus oophorus & & & & +++ \\
\hline \multirow[t]{3}{*}{ Calf (6 months) } & Oocyte & ++ & ++ & ++ & ++ \\
\hline & Granulosa cells & - & + & ++ & + \\
\hline & Cells of the cumulus oophorus & & & & ++ \\
\hline \multirow[t]{3}{*}{ Fetus (5-9 months) } & Oocyte & + & $+/-$ & + & + \\
\hline & Granulosa cells & - & & ++ & + \\
\hline & Cells of the cumulus oophorus & & & & ++ \\
\hline \multirow[t]{2}{*}{ Fetus (3-5 months) } & Oocyte & + & + & & \\
\hline & Granulosa cells & - & - & & \\
\hline
\end{tabular}

- = No signal; +/- = single cells; + = weak signal $+++=$ distinct signal $;+++=$ strong signal.

\section{Carbohydrate Structures of Zona Glycoproteins}

Although it has been demonstrated in several species that carbohydrates of the ZP play a crucial role in gamete recognition [Sinowatz et al., 1998; Töpfer-Petersen, 1999; Nixon et al., 2001; Oehninger, 2001; Wassarman and Litscher, 2001], our knowledge of the oligosaccharide structures of the mammalian zona is still limited [Nakano and Yonezawa, 2001]. One approach to characterizing the carbohydrates of the ZP in situ is the histochemical use of specific sugar-binding proteins (lectins). A wide panel of commercially available lectins with narrow sugar specificity allows the identification of distinct carbohydrate structures of the ZP in tissue sections [Shalgi et al., 1991; Aviles et al., 1994; Maymon et al., 1994; Netzer, 1994; Skutelsky et al., 1994; Steyer, 1994; Wiche, 1994; Trede, 1995; Bollwein, 1998; Bordasch, 1998; Heigl, 1998]. Comparative cytochemical studies manifest species-dependent variations in the expression and distribution of sugar moieties throughout the ZP. Thus, the organization of the ZP in distinct layers, which have been demonstrated by microscopic studies in various species, appears to be accompanied by a spatial distribution of defined sugar structures throughout the width of the ZP [Shalgi et al., 1991]. The lectin-binding pattern in different species is highly specific (fig. 3). In rodents, this pattern varies only in the expression of ligand sites for $\alpha$-galactose and/or $\beta$-N-acetylgalactosamine-recognizing lectins. Interestingly, binding of these lectins is not detectable in the ZP of the human, dog, cat and pig. In general, the increasing variation of lectinbinding patterns correlates with evolution ary distance of species [Shalgi and Raz, 1997]. Some carbohydrate structures are found in all species examined. These are predominantly sugar residues such as mannose and $\mathrm{N}$-acetylglucosamine, which are usually part of the core region of Nlinked oligosaccharides [Geyer and Geyer, 1998]. The lectin histochemical studies demonstrate that most variations appear to affect the terminal nonreducing region of the ZP sugar chains supporting the idea that even small structural differences may contribute to the establishment of the species-specific nature of gamete interaction.

All ZP glycoproteins studied so far possess both Nlinked and O-linked oligosaccharides [Noguchi and Nakano, 1992; Wassarman, 1992; Hokke et al., 1993; Nagdas et al., 1994; Nakano and Yonezawa, 2001]. Galactosyl (Gal) in $\alpha$-linkage was found on the O-linked oligosaccharide chain of mouse ZP3 [Bleil and Wassarman, 1988] as well as $\mathrm{N}$-acetylglucosaminyl (GlcNAc) residues [Miller et al., 1992]. Mouse ZP2 and ZP3 also possess N-linked high mannose hybrid oligosaccharide chains [Tulsiani et al., 1992], N-linked polyl-N-acetyllactosamine glycans and O-linked trisaccharide with the structure GlcNAc$\beta 1,3 \mathrm{Gal} 1,3 \mathrm{GalNAcol}$ [Nagdas et al., 1994]. In addition, $\mathrm{N}$-linked oligosaccharides of mouse ZP2 and ZP3 are mainly fucosylated with tri- and tetraantennary complextype chains with a similar structure [Noguchi and Nakano, 1992].

Due to the establishment of methods for large scale isolation of ZP from pig ovaries the structure of the ZP oligosaccharides has been thoroughly investigated in this species. Porcine ZP glycoproteins can be resolved electrophoretically into two components, with molecular masses of 

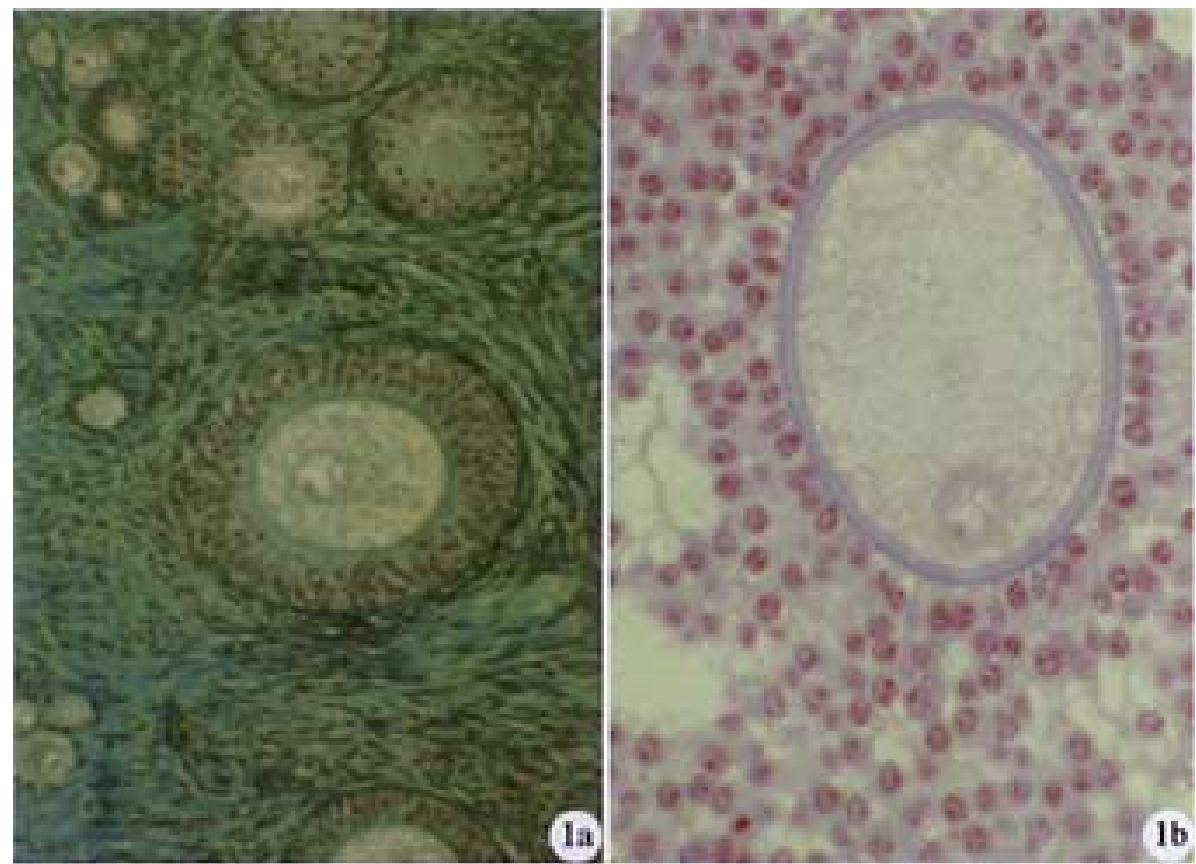

Fig. 1. a Canine ovary, follicles in different stages of their development. Masson-Goldner staining. Bar: $50 \mu \mathrm{m}$. b Oocyte of a bovine tertiary follicle, Azan staining. The ZP appears distinctly stratified. Bar: $25 \mu \mathrm{m}$. c TEM photograph of a bovine secondary follicle. Between the oocyte and the follicular epithelium electron-dense material forms the ZP. Bar: $20 \mu \mathrm{m}$. d Gap junctions between processes of the follicle cells and the plasma membrane of the oocyte. Bar: $3 \mu \mathrm{m}$.

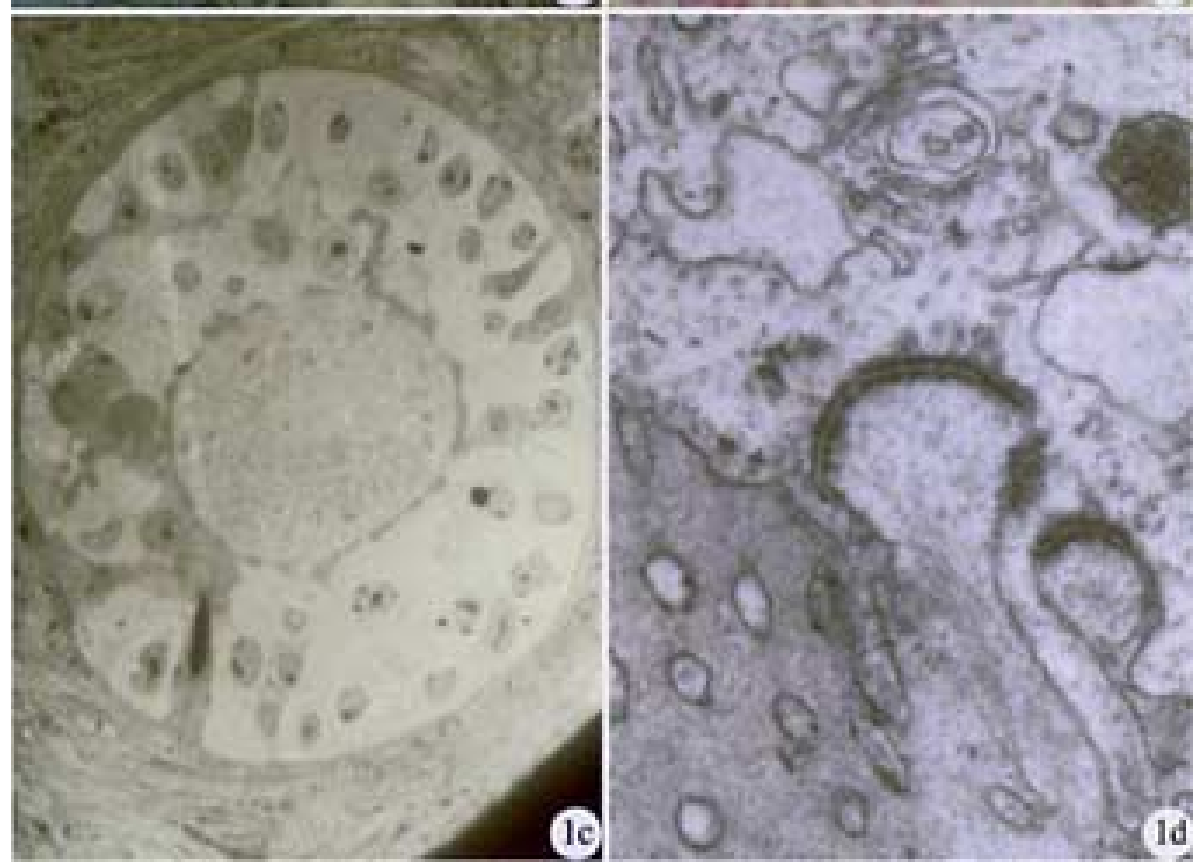

about 55 and $90 \mathrm{kD}$ [Hedrick and Wardrip, 1986]. The $55-\mathrm{kD}$ component, representing about $80 \%$ of the total protein content of the porcine $\mathrm{ZP}$, consists of two distinct polypeptides, referred to as pZPB and pZPC. Sperm receptor activity has been correlated to $\mathrm{pZPB}$, whereas pZPC is the homologue of the mouse ZP3 protein, a member of the ZPC family. Both proteins can be separated only after partial deglycosylation with endo- $\beta$-galactosi-

Biosynthesis and Expression of Zona pellucida Glycoproteins in Mammals dase [Sacco et al., 1989]. According to the deduced cDNA-encoded amino acid sequence, each of the proteins may possess up to five potential $\mathrm{N}$-glycosylation sites [Harris et al., 1994]. Carbohydrate composition analysis, however, suggested that the pZPB and pZPC proteins contain three or four $\mathrm{N}$-linked oligosaccharide chains and additionally three (pZPB) and six (pZPC) O-linked glycan chains [Yurewicz et al., 1992].

Cells Tissues Organs 2001;168:24-35 29 
Fig. 2. a Immunocytochemical demonstration of ZPC in the porcine ovary. Around the oocytes of primary follicles immunopositive material is seen as first sign of the developing ZP. Bar: $50 \mu \mathrm{m}$. b Immunocytochemical demonstration of ZPC in the porcine ovary. In secondary follicles a distinct immunopositive ZP can be observed. Bar: $50 \mu \mathrm{m}$. c Immunocytochemical demonstration of $\mathrm{ZPC}$ in the porcine ovary. Besides the ZP also the cytoplasm of follicle cells surrounding the oocyte contain a distinct amount of immunopositive ZPC. Bar: $40 \mu \mathrm{m}$. d Immunocytochemical demonstration of ZPC in the canine ovary. Parts of the zona and several of the surrounding follicle cells are distinctly immunopositive. Bar: $50 \mu \mathrm{m}$.

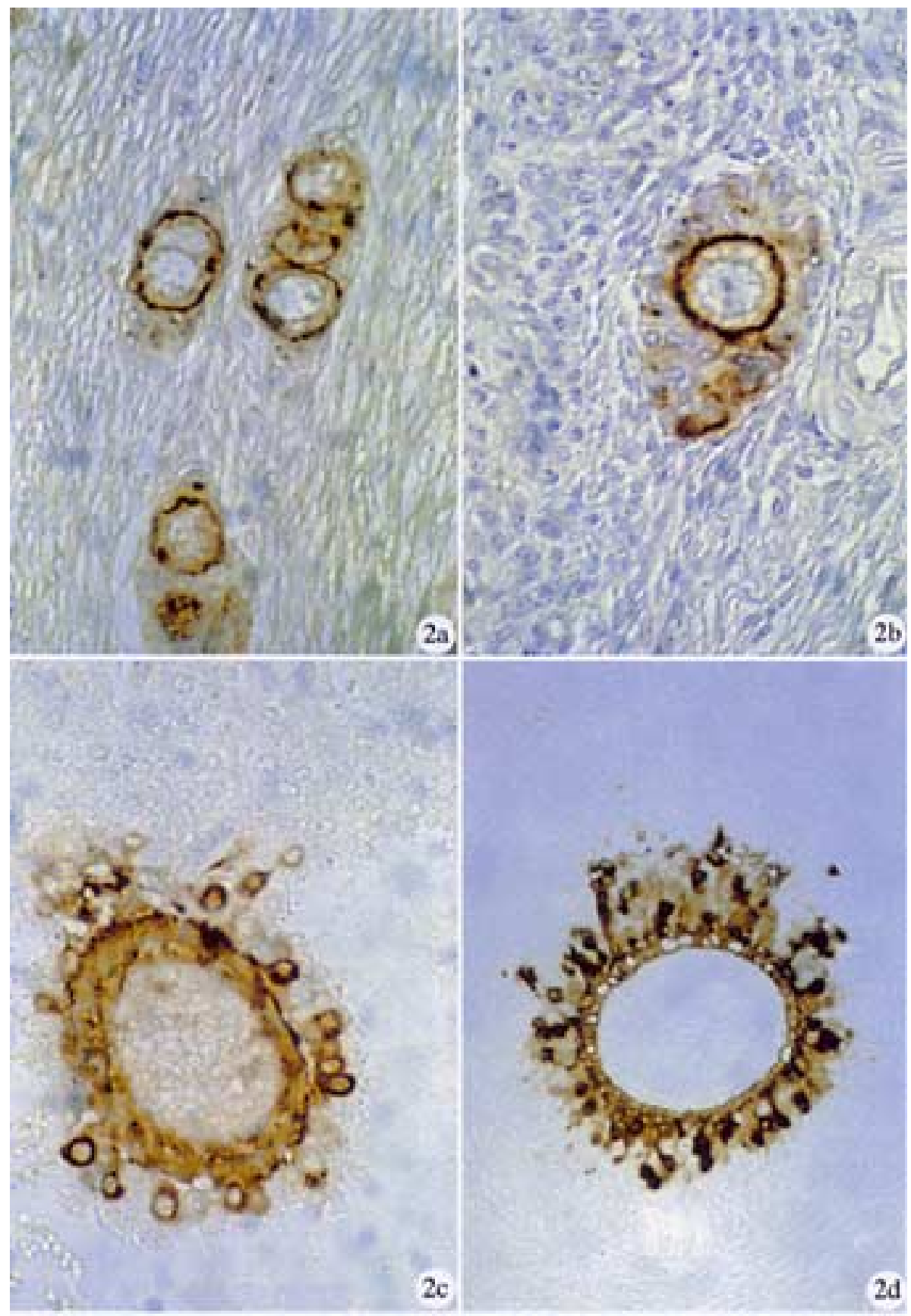

The N-linked oligosaccharides, released by hydrazinolysis from the $55-\mathrm{kD}$ family of porcine $\mathrm{ZP}$ glycoproteins, were separated into neutral (28\%) and acidic (72\%) carbohydrate chains by anion exchange HPLC [Noguchi et al., 1992]. A competition assay revealed that the mixture of neutral chains acts as sperm receptor, while acidic chains have no activity [Nakano and Yonezawa, 2001]. More than 30 different structures of N-linked oligosaccharides have been identified in the neutral fraction. The most abundant neutral structure is a biantennary oligosaccharide which commonly is found in other glycoproteins. Some structures lack a terminal non reducing galactose residue at the $\alpha 1,3-$ or man $\alpha 1,6$-arms of the trimannosyl core or they contain linear $\mathrm{N}$-acetyllactosamine repeats in their outer chains [Mori et al., 1989; Noguchi and Nakano, 1992]. The acidic N-linked sugar chains of the $55-\mathrm{kD}$ com- 
Fig. 3. a Canine ovary, incubation with concanavalin-FITC. The ZP is distinctly stained. Bar: $30 \mu \mathrm{m}$. b Canine ovary, incubation with Urtica dioica agglutinin-FITC. The inner layer of the ZP and several of the surrounding follicle cells are positive. Bar: 30 $\mu \mathrm{m}$. c Canine ovary, incubation with Maclura pomifera agglutinin-FITC. This tertiary follicle contains 3 oocytes. Their zonae appear distinctly labeled. Bar: $50 \mu \mathrm{m}$. d Porcine ovary, Graaf follicle. Incubation with $U$. dioica agglutinin-FITC results in a marked staining of the ZP. Bar: $120 \mu \mathrm{m}$.

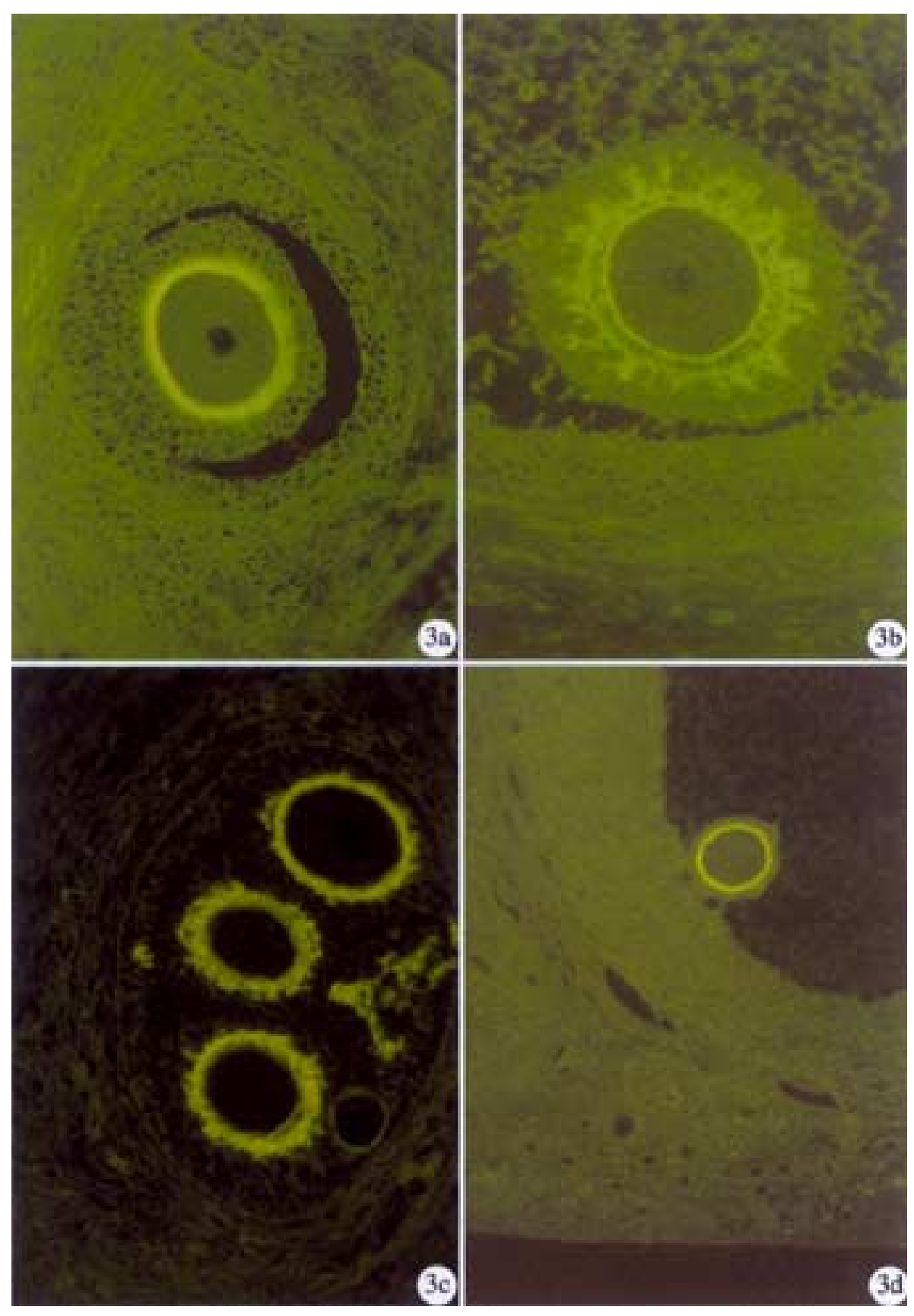

ponents occur as di-, tri-, and tetraantennary structures. They can be sialylated and/or, as in most cases, sulfated at the poly-N-acetyllactosamine units. The major acidic nonsulfated components are sialylated (with Neu5Gc/Ac residues), biantennary and 4,2-branched, triantennary acidic chains. The sulfate groups are exclusively 1,6-linked to the $\mathrm{N}$-acetylglucosamine residues of the $\mathrm{N}$-acetyllactosamine repeats [Noguchi and Nakano, 1992].

Biosynthesis and Expression of Zona pellucida Glycoproteins in Mammals
The acidic poly-N-acetyllactosamine backbone of the O-linked oligosaccharides exhibits the same structure as in the N-linked glycans extending from the Gal $\beta 1,3 \mathrm{Gal}-$ NAc disaccharide core. Interestingly, the longer chains predominantly terminate with $\mathrm{Neu} 5 \mathrm{Gc} / \mathrm{Ac}$ residues which are $\alpha 2,3$-linked to a galactose residue of the outermost lactosamine unit. Shorter chains with no or only one $\mathrm{N}$-acetyllactosamine unit are also $\alpha 2,6$-sialylated at the

Cells Tissues Organs 2001;168:24-35 31 
proximal $\mathrm{N}$-acetylgalactosamine residue. Neutral structures with $\alpha$-galactose and $\beta$ - $\mathrm{N}$-acetylglucosamine residues and minor components with $\alpha$-galactose and $\beta-\mathrm{N}$ acetylgalactosamine residues at their nonreducing termini have also been identified [Hirano et al., 1993; Hokke et al., 1993, 1994; Sinowatz et al., 1997, 1998; Nakano and Yonezawa, 2001]. The amount of sulfated $\mathrm{N}$-acetyllactosamine repeats and the degree of sialylation contribute to the enormous heterogeneity of the carbohydrate portion of the ZP matrix. More than 30 different O-linked structures have been identified in porcine $\mathrm{ZP}$ glycoproteins and the diversity of the acidic $\mathrm{N}$-linked structures appears to be even larger.

Several forms of evidence refer to different carbohydrate residues present on the $\mathrm{ZP}$ as key molecules in the process of sperm-egg interaction. In mouse and pig the sperm receptor activity has been attributed mainly to a certain class of O-linked oligosaccharides [Florman and Wassarman, 1985; Yurewicz et al., 1991]. At present this interpretation is not easily reconcilable with the possibility of neutral N-linked carbohydrates being involved in the binding event [Noguchi et al., 1992; Töpfer-Petersen et al., 1995; Nakano and Yonezawa, 2001]. In both species the clustering of the biologically active carbohydrate moieties appears to be necessary to achieve high-affinity binding. In mouse the active sperm receptor region has been mapped to the C-terminal $28-\mathrm{kD}$ peptide of mZP3 [Rosiere and Wassarman, 1992; Wassarman and Litscher, 2001]. In pig trypsin digestion of isolated pZPB and pZPC glycoproteins produced a single O-glycosylated domain from each glycoprotein containing three to five $\mathrm{O}$ linked glycosylation sites, respectively. The O-glycosylated domain of the pZPB protein only retained sperm receptor activity, indicating that both $\mathrm{ZP}$ glycoproteins may have a different O-glycosylation pattern. The poly$\mathrm{N}$-acetyl-lactosamine units, however, do not appear to play a role in sperm binding [Yurewicz et al., 1992]. The amino acid sequences of the O-glycosylated regions are highly conserved within the ZPB and ZPC protein families. It was recently demonstrated [Yonezawa et al., 1999; Nakano and Yonezawa, 2001] that neutral N-linked carbohydrates from pig ZPB/ZPC mixture possess sperm ligand activity. Of these complex-type chains, triantennary/tetraantennary chains exhibit a stronger binding activity compared to that of diantennary chains. Their results further suggest that the carbohydrate chains linked to Asn220 of ZPB participate predominantly in spermegg binding. ZPC has been shown to support the expression of sperm ligand activity of ZPB.
In species other than pig various carbohydrates were suggested to function as sperm receptor. Inhibition assays of sperm ZP binding revealed a role for $D$-mannose in human and rat ZP. Pretreatment of human spermatozoa with $D$-mannose inhibited sperm penetration through the ZP [Mori et al., 1989]. In rat $\alpha$-methyl mannoside and $D$-mannose turned out to be the most potent inhibitors [Shalgi et al., 1986]. $L$-Fucose and the sulfate algal fucan fucoidin were shown to be involved in sperm ZP recognition in guinea pig, hamster, rat and human oocytes [Huang et al., 1982; Shalgi et al., 1986]. New data in human suggest that sperm binding to $\mathrm{ZP}$ requires a 'selectin-like' interaction [Oehninger, 2001].

\section{Postovulatory Changes in the Composition of the ZP}

After fertilization the cortical reaction prevents polyspermy in mammals. Its effect on the composition of the murine ZP has recently been studied in some detail by Green [1997], who demonstrated that material released by cortical granules and bound by the ZP could significantly contribute to the mass of ZP post fertilization. The released material was distributed predominantly on the inner face of the ZP and its local concentration could approach that of ZP1. It was postulated that the material released from cortical granules could block polyspermy by direct titration of ZP-binding sites. This would be an alternative to an older hypothesis that the zona block is due to cleavage of ZP2 to ZP2f.

The oviduct provides the optimal milieu for fertilization and early embryo development. It has been demonstrated in several studies that the oviduct is also involved in the final elaboration of the ZP of the ovulated oocyte by secreting ZP-binding glycoproteins [Mallete and Bleau, 1993; Malette et al., 1995a, b; Buhi et al., 2000]. Such proteins have been found in rabbit [Shapiro et al., 1974], pig [Hedrick and Wardrip, 1986], sheep [Gandolfi et al., 1989], baboon [Boice et al., 1990], mouse [Kapur and Johnson, 1985] and hamster [Mallete and Bleau, 1993]. These glycoproteins are now collectively designated as oviductins. Recent reports on the cloning of cDNAs of oviductins from various species, including human, allowed the comparison of the deduced amino acid sequence with those of other proteins. Alignment analysis demonstrated that oviductins contain regions of significant similarity with catalytically inactive mammalian members of the bacterial and microfilarial chitinase protein family [Malette et al., 1995a]. A close examination of 
the hamster- and the human-deduced amino acid sequences showed that both glycoproteins possess contiguous Ser/Thr-rich repeated units, clustered in their carboxy-terminal region. This interesting feature might indicate that oviductins could play a similar role in mucintype glycoproteins [Lagow et al., 1999], e.g. protect the oocyte and early embryos against detrimental influences from their environment. Malette et al. [1995a] suggested that oviductins are targeted to the oocyte via the interaction of their chitinase-like domain with specific oligosaccharide moieties of the $\mathrm{ZP}$. Once bound to the $\mathrm{ZP}$, ovi- ductin molecules could act as a protective layer around the oocyte and early embryo by virtue of their densely glycosylated mucin-type domains.

\section{Acknowledgments}

Studies done in the authors' laboratories have been financed by grants from the Bundesministerium für Forschung und Technologie, Bonn, Germany (01KY9103; F.S. and E.T.-P.) and from the Deutsche Forschungsgemeinschaft (To114/3-1 to To114/3-3; E.T.-P.).

\section{References}

Ahuja, K.K., G.P. Bolwell (1983) Probable asymmetry in the organization of components of the hamster zona pellucida. J Reprod Fertil 69: 4955.

Aitken, J. (1995) The complexities of conception. Science 269: 39-40.

Aviles, M., J.A. Martinez-Menarguez, M.T. Castells (1994) Cytochemical characterization of oligosaccharide side chains of the glycoproteins of rat zona pellucida: An ultrastructural study. Anat Rec 239: 127-149.

Bedford, J.M. (1977) Sperm/egg interaction: The specificity of human spermatozoa. Anat Rec 188: 477-483.

Berger, T., K.O. Turner, S. Meizel, J.L. Hedrick (1989) Zona pellucida induced acrosome reaction in boar sperm. Biol Reprod 40: 525-530.

Bleil, J.D., P.M. Wassarman (1980) Structure and function of the zona pellucida: Identification and characterization of the proteins of the mouse oocyte's zona pellucida. Dev Biol 76 . 185-202.

Bleil, J.D., P.M. Wassarman (1988) Galactose at the nonreducing terminus of O-linked oligosaccharides of mouse oocyte zona pellucida glycoprotein ZP3 is essential for the glycoprotein's sperm receptor activity. Proc Natl Acad Sci USA 85: 6778-6782.

Bleil, J.D., P.M. Wassarman (1990) Identification of a ZP3-binding protein on acrosome-intact mouse sperm by photoaffinity crosslinking. Proc Natl Acad Sci USA 87: 5563-5567.

Boice, M.L., R.D. Geisert, R.M. Blair, H.G. Verhage (1990) Identification and characterization of bovine oviductal glycoproteins synthesized at estrus. Biol Reprod 43: 547-465.

Bollwein, T. (1998) Histologische und histochemische Untersuchungen am Ovar des Hausschafes (Ovis ammon aries); thesis, University of Munich.

Bordasch, I. (1998) Histologische, lektin- und immunhistochemische Untersuchungen am Ovar der Katze (Felis domestica); thesis, University of Munich.

Bork, P. (1992) Mobile modules and motifs. Curr Opin Struct Biol 2: 413-421.
Bork, P. (1993) A trefoil domain in the major rabbit zona pellucida protein. Protein Sci 2: 669670.

Bork, P., G. Beckmann (1993) The CUB domain. A widespread module in developmentally regulated proteins. J Mol Biol 231: 539-545.

Bork, P., C. Sander (1992) A large domain common to sperm receptors (ZP2 and ZP3) and TGF- $\beta$ type III receptor. Fed Eur Biochem Soc 300: 237-240.

Buhi, W.C., I.M. Alvarez, A.J. Kouba (2000) Secreted proteins of the oviduct. Cells Tissues Organs 166: 165-179.

Cherr, G.N., H. Lambert, S. Meizel, D.F. Katz (1986) In vitro studies of the golden hamster acrosome reaction. Completion on the zona pellucida and induction by homologous soluble zonae pellucidae. Dev Biol 114: 119-131.

Denker, H.-W. (2000) Structural dynamics and function of early embryonic coats. Cells Tissues Organs 166: 180-207.

Dunbar, B.S., S. Avery, V. Lee, S. Prasad, D. Schwahn, E. Schwoebel, S. Skinner, Wilkins, B. (1994) The mammalian zona pellucida: Its biochemistry, immunochemistry, molecular biology and development expression. Reprod Fertil Dev 6: 331-347.

Dunbar, B.S., G.A. Maresh, K. Washenik (1989) Ovarian development and formation of the mammalian zona pellucida; in Dietl, J.J. (ed): The Mammalian Egg Coat: Structure and Function. Berlin, Spinger, pp 38-48.

Epifano, O., L.F. Liang, M. Familari, M.C. Moos Jr, J. Dean (1995) Coordinate expression of the three zona pellucida genes during mouse oogenesis. Development 121: 1947-1956.

Fléchon, J.E., A. Pavlok, V. Kopecny (1984) Dynamics of the zona pellucida formation by mouse oocyte: An autoradiographic study. Biol Cell 51: 403-406.

Florman, H.M., B.T. Storey (1982) Mouse gamete interactions: The zona pellucida is the site of the acrosome reaction leading to fertilization in vitro. Dev Biol 91: 121-130.

Florman, H.M., H.P. Wassarman (1985) O-linked oligosaccharides of mouse egg ZP3 account for its sperm receptor activity. Cell 41: 313-324.
Gandolfi, F., T.A. Brevini, L. Richardson, C.R. Brown, R.M. Moor (1989) Characterization of proteins secreted by sheep oviduct epithelial cells and their function for embryonic development. Developement 106: 303-312.

Geyer, H., R. Geyer (1998) Strategies for glycoconjugate analysis. Acta Anat 161: 135-148.

Green, D.P. (1997) Three-dimensional structure of the zona pellucida. Rev Reprod 2: 147-156.

Grootenhuis, A.J., H.L. Philipsen, J.T. de BreetGrijsbach, M. van Duin (1996) Immunocytochemical localization of ZP3 in primordial follicles of rabbit, marmoset, rhesus monkey and human ovaries using antibodies against human ZP3. J Reprod Fertil Suppl 50: 43-54.

Haddad, A., M.E.T. Nagai (1977) Radioautographic study of glycoprotein biosynthesis and renewal in the ovarian follicles of mice and the origin of the zona pellucida. Cell Tissue Res 177: 347-369.

Harris, J.D., D.W. Hibler, G.K. Fonteno, K.T. Hsu, E.C. Yurewicz, A.G. Sacco (1994) Cloning and characterization of zona pellucida genes and cDNAs from a variety of mammalian species: The ZPA, ZPB and ZPC gene families. DNA Seq 4: 361-393.

Hedrick, J.L., N.J. Wardrip (1986) Isolation of the zona pellucida and purification of its glycoprotein families from pig oocytes. Dev Biol 121: 478-488.

Heigl, M. (1998) Zytochemische, lektinhistochemische und immunzytochemische Untersuchungen am Ovar der Hündin (Canis familiaris); thesis, University of Munich.

Herrler, A., H.M. Beier (2000) Early embryonic coats: Morphology, function, practical applications. An overview. Cells Tissues Organs 166: 233-246.

Hirano, T., S. Takasaki, J.L. Hedrick, N.J. Wardrip, J. Amano, A. Kobata (1993) O-linked neutral sugar chains of porcine zona pellucida glycoproteins. Eur J Biochem 214: 763-769.

Hokke, C.H., J.B.L. Damm, J.P. Kamerling, J.F.G. Vliegenhart (1993) Structure of three acidic Olinked carbohydrate chains of porcine zona pellucida glycoproteins. FEBS Lett 329: 29-34. 
Hokke, C.H., J.B.L. Damm, B. Penninkhof, R.J. Aitken, J.P. Kammerling, J.F.G. Vliegenhart (1994) Structure of the O-linked carbohydrate chains of porcine zona pellucida glycoproteins. Eur J Biochem 221: 491-512.

Hoshiba, H., F. Sinowatz (1998) Immunohistochemical localization of the spermadhesin AWN-1 in the equine male genital tract. Anat Histol Embryol 27: 351-353.

Huang, T.T.F., E. Ohzu, R. Yanagimachi (1982) Evidence suggesting that $L$-fucose is part of a recognition signal for sperm-zona pellucida attachment in mammals. Gamete Res 5: 355361.

Jegenow, K., J. Fickel (1999) Sequential expression of zona pellucida protein genes during oogenesis of domestic cats. Biol Reprod 60: 522-526.

Kapur, R.P., L.V. Johnson (1985) An oviductal fluid glycoprotein associated with ovulated mouse ova and early embryos. Dev Biol 112: 89-93.

Keefe, R.G., D.A. Ferrick, J.L. Scott (1997) Cytokine transcription in lymph nodes of cattle in different stages of bovine leukemia virus infection. Vet Immunol Immunpathol 59: 271283.

Kimura, J., K. Sato, M. Okano, A. Tsukise (1994) Localization of ZP3 mRNA in mouse ovary by non-radioactive in situ hybridization with digoxigenin-labelled cDNA. Cell Mol Biol 40: 1097-1101.

Kölle, S., F. Sinowatz, G. Boie, G. Palma (1998) Differential expression of ZPC in the bovine ovary, oocyte and embryo. Mol Reprod Dev 49: 435-443.

Kölle, S., F. Sinowatz, G. Boie, I. Totzauer, W. Amselgruber, J. Plendl (1996) Localization of the mRNA encoding the zona protein $\mathrm{ZP} 3 \alpha$ in the porcine ovary, oocyte and embryo by nonradioactive in situ hybridization. Histochem $\mathbf{J}$ 28: 441-447.

Lagow, E., M. DeSouza, D.D. Carson (1999) Mammalian reproductive tract mucins. Hum Reprod Update 5: 280-292

Liu, C., E.S. Litscher, P.M. Wassarman (1997) Zona pellucida glycoprotein mZP3 bioactivity is not dependent on the extent of glycosylation of its polypeptide or on sulfation and sialylation of its oligosaccharides. J Cell Sci 110: 745752 .

Malette, B., G. Bleau (1993) Biochemical characterization of hamster oviductin as a sulphated zona pellucida-binding protein. Biochem $\mathbf{J}$ 293: 437-445.

Malette, B., B. Filion, S. St-Jaques, F.W. Kan, G. Bleau (1995b) Hormonal control of the biosynthesis of hamster oviductin. Microsc Res Tech 31: 470-477.

Malette, B., Y. Paquette, Y. Merlen, G. Bleau (1995a) Oviductin possess chitinase and mucin-like domains: A lead in the search for the biological function of these oviduct-specific ZP-associating glycoproteins. Mol Reprod Dev 41: 384-397.

Maymon, B.B., R. Maymon, I. Ben-Nun (1994) Distribution of carbohydrates in the zona pellucida of human oocytes. J Reprod Fertil 102. 81-86.
Martinez, M.L., G.K. Fontenot, J.D. Harris (1996) The expression and localization of zona pellucida glycoproteins and mRNA in cynomolgus monkeys (Macaca fascicularis). J Reprod Fertil suppl 50: 35-41.

McLeskey, S.B., C. Dowds, R. Carballada, R. White, P.M. Saling (1998) Molecules involved in mammalian sperm-egg interaction. Int Rev Cytol 177: 57-113.

Miller, D.J., M.B. Macek, B.D. Shur (1992) Complementarity between sperm surface $\beta 1$,4-galactosyltransferase and egg-coat ZP3 mediates sperm-egg binding. Nature 357: 589-593.

Mori, K., T. Daitoh, M. Irahara, M. Kamada, T. Aono (1989) Significance of $D$-mannose as a sperm receptor site on the zona pellucida in human fertilization. Am J Obstet Gynecol 161 . 207-221.

Nagdas, S.K., Y. Araki, C.A. Chayko, M.C. Orgebin-Crist, D.R.P. Tulsiani (1994) O-linked trisaccharide and N-linked poly-N-acetyllactosaminyl glycans present on mouse ZP2 and ZP3 Biol Reprod 51: 262-272.

Nakano, M., N. Yonezawa (2001) Localization of sperm-ligand carbohydrate chains in pig zona pellucida glycoproteins. Cells Tissues Organs 168: 65-75.

Nixon, B., L. Qingxian, M.J. Wassler, C.I. Foote, M.A. Ensslin, B.D. Shur (2001) Galactosyltransferase function during mammalian fertilization. Cells Tissues Organs 168: 46-57.

Netzer, E. (1994) Histologische und histochemische Untersuchungen an der Zona pellucida von Kälbern und adulten Rindern, sowie Charakterisierung der Zona pellucida anhand elektrophoretischer Untersuchungen und Immunblots; thesis, University of Munich.

Nikas, G., T. Paraschos, A. Psychoyos, A.H. Handyside (1994) The zona reaction in human oocytes as seen with scanning electron microscopy. Hum Reprod 11: 2135-2138.

Noguchi, S., Y. Hatanaka, T. Tobita (1992) Structural analysis of the N-linked carbohydrate chains of the $55-\mathrm{kDa}$ glycoprotein family (pZP3) from porcine zona pellucida. Eur J Biochem 209: 1089-1100.

Noguchi, S., M. Nakano (1992) Structure of the acidic N-linked carbohydrate chains of the 55$\mathrm{kDa}$ glycoprotein family (pZP3) from porcine zona pellucida. Eur J Biochem 209: 883-894.

Noguchi, S., N. Yonezawa, T. Katsumata, K. Hasizume, M. Kuwayama, S. Hamano, S. Watanabe, M. Nakano (1994) Characterization of the zona pellucida glycoproteins from bovine ovarian and fertilized eggs. Biochim Biophys Acta 1201: 7-14.

Philips, D.M., R.M. Shalgi (1980) Surface properties of the zona pellucida. J Exp Zool 213: 1-8.

Oehninger, S. (2001) Molecular basis of human sperm-zona pellucida interaction. Cells Tissues Organs 168: 58-64.

Rosiere, T., P.M. Wassarman (1992) Identification of a region of mouse zona pellucida glycoprotein $\mathrm{mZP} 3$ that possesses sperm receptor activity. Dev Biol 154: 309-317.
Sacco, A.G., E.C. Yurewicz (1989) Use of the zona pellucida as an immunocontraceptive target antigen; in Dietl, J. (ed): The Mammalian Egg Coat. Berlin, Springer, pp 128-153.

Sacco, A.G., E.C. Yurewicz, M.G. Subramanian, P.D. Matzat (1989) Porcine zona pellucida: Association of sperm receptor activity with the $\alpha$ glycoprotein component of the $\mathrm{M}_{\mathrm{r}}=55,000$ family. Biol Reprod 41: 523-532.

Schellander, K., F. Fuhrer, B.G. Brackett, H. Korb, W. Schleger (1990) In vitro fertilization and cleavage of bovine oocytes matured in medium supplemented with estrous cow serum. Theriogenology 33: 477-485.

Shivers, C.A., B.S. Dunbar (1997) Autoantibodies to zona pellucida: A possible cause of infertility in women. Science 197: 1082-1084.

Schultz, R.M., G.E. Letourneau, P.M. Wassarman (1979) Program of early development in the mammal: Changes in patterns and absolute rates of tubulin and total protein synthesis during oogenesis and early oogenesis in the mouse. Dev Biol 68: 341-359.

Shalgi, R., B. Maymon, B. Bar-Shira (1991) Distribution of lectin receptor sites in the zona pellucida of follicular and ovulated oocytes. Mol Reprod Dev 29: 365-372.

Shalgi, R., A. Mitityahu, L. Nebel (1986) The role of carbohydrates in sperm-egg interaction in rats. Biol Reprod 34: 446-452.

Shalgi, R., T. Raz (1997) The role of carbohydrate residues in mammalian fertilization. Histol Histopathol 12: 813-822.

Shapiro, S., S. Brown, A.S. Yard (1974) Isolation of an acidic glycoprotein from rabbit oviducal fluid and its association with the egg coating. J Reprod Fertil 40: 281-290.

Sinowatz, F., W. Amselgruber, E. Töpfer-Petersen, I. Totzauer, J.J. Calvete, J. Plendl (1995) Immunocytochemical characterization of porcine zona pellucida during follicular development. Anat Embryol 191: 41-46.

Sinowatz, F., S. Kölle, J. Plendl (1998) Protein-carbohydrate interactions during fertilization. Acta Anat 161: 196-205.

Sinowatz, F., E. Töpfer-Petersen, J.J. Calvete (1997) Glycobiology of fertilization; in Gabius, H.J., S. Gabius (eds): Glycosciences - Status and Perspectives. Weinheim, Chapman \& Hall, pp 595-610.

Sinowatz, F., E. Töpfer-Petersen, S. Kölle, J. Plendl (2000) Structure and function of the zona pellucida in domestic animals. Anat Histol Embryol, in press

Skinner, S.M., T. Mills, H.J. Kirchick, B.S. Dunbar (1984) Immunization with zona pellucida proteins results in abnormal ovarian follicular differentiation and inhibition of gonadotropin induced steroid secretion. Endocrinology 115: 2418-2432.

Skinner, S.M., S.V. Prasad, T.M. Ndolo, B.S. Dunbar (1996) The mammalian zona pellucida: Its biochemistry, immunochemistry, molecular biology, and development expression. Reprod Fertil Dev 4: 59-76. 
Skutelsky, E., E. Ranen, R. Shalgi (1994) Variations in the distribution of sugar residues in the zona pellucida as possible species-specific determinants of mammalian oocytes. J Reprod Fertil 100: 35-41.

Steyer, E. (1994) Ultrastrukturelle, biochemische und histochemische Untersuchungen der Zona pellucida des Rindes; thesis, University of Munich

Suzuki, H., X. Yang, R.H. Foote (1994): Surface alterations of the bovine oocyte and its investments during and after maturation and fertilization in vitro. Mol Reprod Dev 38: 421-430.

Töpfer-Petersen, E. (1999) Carbohydrate-based interactions on the route of a spermatozoon to fertilization. Hum Reprod Update 5: 314329

Töpfer-Petersen, E., J.J. Calvete, L. Sanz, F. Sinowatz (1995) Carbohydrate- and heparin-binding proteins in mammalian fertilization. Andrologia 27: 303-324.

Totzauer, I., S. Kölle, F. Sinowatz, J. Plendl, W. Amselgruber, E. Töpfer-Petersen (1998) Localization of the zona glycoproteins ZPB (ZP3 $\alpha$ ) and $\mathrm{ZPC}(\mathrm{ZP} 3 \beta)$ in the bovine ovary during pre- and postnatal development. Ann Anat 180: $37-43$.

Trede, C. (1995) Histologische, ultrastrukturelle und histochemische Untersuchungen an der Zona pellucida des Schweines; thesis, University of Munich.

Tresoriero, J.V. (1981) Early ultrastructural changes of developing oocytes in the dog. $\mathbf{J}$ Morphol 168: 171-179.

Tulsiani, D.R., S.K. Nagdas, G.A. Cornwall, M.C Orgebin-Crist (1992) Evidence for the presence of high-mannose/hybrid oligosaccharide chain(s) on the mouse ZP2 and ZP3. Biol Reprod 46: 93-100.
Vanroose, G., H. Nauwcynck, A. Van Soom, E. Vanopendenbosch, A. de Kruif (1997) Susceptibility of zona-intact and zona-free in vitro produced bovine embryos at different stages of development to infections with bovine herpesvirus-1. Theriogenology 47: 1389-1402.

Vanroose, G., H. Nauwynck, A. Van Soom, E. Vandopendenbosch, A. de Kruif (1998) Replication of cytopathic and noncytopathic bovine viral diarrhea virus in zona-free and zonaintact in vitro produced bovine embryos and the effect on embryo quality. Biol Reprod 58: 857-866.

Vanroose, G., H. Nauwynck, A. Van Soom, M.T. Ysebaert, G. Charlier, P. Van Oostveldt, A. de Kruif (2000): Structural aspects of the zona pellucida of in vitro-produced bovine embryos: A scanning electron and confocal laser scanning microscopic study. Biol Reprod 62: 463-469.

Wassarman, P.M. (1982) Fertilization; in Yamada, K. (ed): Cell Interactions and Development. Molecular Mechanisms. New York, Wiley, pp $1-27$.

Wassarman, P.M. (1991) Cell surface carbohydrates and mammalian fertilization; in Fukuda, M. (ed): Cell Surface Carbohydrates and Cell Development. Boca Raton, CRC Press, pp 140-164.

Wassarman, P.M. (1992) Regulation of mammalian fertilization by gamete adhesion molecules; in Nieschlag, E., U.F. Habenicht (eds): Spermatogenesis, Fertilization, Contraception. Molecular, Cellular and Endocrine Events in Male Reproduction. Berlin, Springer, pp 345-366.

Wassarman, P.M. (1999) Mammalian fertilization: Molecular aspects of gamete adhesion, exocytosis, and fusion. Cell 96:175-183.
Wassarman, P.M., E.S. Litscher (2001) Towards the molecular basis of sperm and egg interaction during mammalian fertilization. Cells Tissues Organs 168: 36-45.

Wassarman, P.M., C. Liu, J. Chen, H. Qi, E.S. Litscher (1998) Ovarian development in mice bearing homozygous or heterozygous null mutations in zona pellucida glycoprotein gene mZP3. Histol Histopathol 13: 293-300.

Wassarman, P.M., S. Mortillo (1991) Structure of the mouse egg extracellular coat, the zona pellucida. Int Rev Cytol 130: 85-110.

Wiche, M. (1994) Histologische und histochemische Untersuchungen am fetalen Rinderovar sowie Charakterisierung der Zona pellucida mittels Elektrophorese und Immunoblot; thesis, University of Munich.

Yanagimachi, R. (1988) Mammalian fertilization; in Knobil, E., J.D. Neill (eds): The Physiology of Reproduction, New York, Raven Press, pp 135-185.

Yanagimachi, R. (1994) Fertility of mammalian spermatozoa: Its development and relativity. Zygote 4: 371-372.

Yonezawa, N., N. Fukui, K. Kudo, M. Nakano (1999) Localization of neutral N-linked carbohydrate chains in pig zona pellucida glycoprotein ZPC. Eur J Biochem 260: 57-63.

Yurewicz, E.C., B.A. Pack, A.G. Sacco (1991) Isolation, composition, and biological activity of sugar chains of porcine oocyte zona pellucida 55K glycoprotein. Mol Reprod Dev 30: 126134

Yurewicz, E.C., B.A. Pack, A.G. Sacco (1992) Porcine oocyte zona pellucida $\mathrm{Mr}$ 55,000 glycoproteins: Identification of O-glycosylated domains. Mol Reprod Dev 33: 182-188. 